\title{
Essay-Review
}

\section{Toward a New Sociology of Human Rights?}

Mikael Rask Madsen and Gert Verschraegen

\author{
The Sacredness of the Person: A New Genealogy \\ of Human Rights \\ Hans Joas \\ Washington, D.C.: Georgetown University Press, \\ 2013. ix +219 .
}

While disciplines such as law, political science, and history have now developed distinct subfields of human rights research, sociology has only recently started developing a clear research agenda with regard to human rights. Considering the importance of human rights in contemporary society as a legal, political, and moral phenomenon underpinning a whole array of social institutions, the late arrival of sociology is all the more surprising. ${ }^{1}$ An important factor for explaining the development of the sociology of human rights is to be found in the tradition of sociology itself. $^{2}$ The strong influence of classical sociologists such as Max Weber, who emphasized the decline of natural law and the concomitant emergence of juridical rationalism, and Karl Marx, who regarded individual rights as mere ideology, has in important ways held back the development of a sociology of human rights. Moreover, the very notion that persons have rights simply because they are human is largely perceived as a philosophical—or worse—ideological abstraction. ${ }^{3}$ Émile Durkheim, Karl Marx, and Max Weber were all highly skeptical about the possibility of and, indeed, need for a universalistic and normative basis for human rights. Instead, they emphasized the much more central roles of law and morality in relationship to the development of particular societal structures. While rights are widely perceived to be presocial, individual, and liberal (serving mainly as protections against coercive state power), Marx as well as Durkheim considered that rights inhere in society and/or the state, rather than in the individual. Consequently, they believed that any discussion of human rights should be firmly linked to the capacity of the state and society at large to guarantee the enjoyment of those rights.

In this light it is hardly surprising that in the period after World War II the sociology of citizenship came to function in many ways as a kind of substitute for a sociology of human rights. ${ }^{4}$ After all, citizenship-defined in the tradition of T. H. Marshall as participation in the civic, political, and welfare institutions of modern society—provides a theoretically viable and empirically tangible sociological alternative to the abstract and universalist idea of human rights. It is bound up with the 
modern state as provider of particularistic, state-dependent, and territorially limited rights and freedoms. To most postwar sociologists conducting research in the industrialized European and Anglo-American societies, such concrete civil and political rights had more significance in the shaping of social life than abstract human rights, which were largely "beyond the scope of national sociologies in which the boundaries of the nation state have been assumed to correspond to 'society." "5

This picture is rapidly changing. In the mid-I99os the issue of human rights effectively entered mainstream sociology, and over recent years it has developed into a more sustained engagement. Early and influential work on human rights by sociologists such as Bryan Turner and Anthony Woodiwiss has been accompanied by a diverse array of sociological research on human rights. ${ }^{6}$ With this growing interest, the research object in focus has also expanded. Contemporary sociological theory and research have increasingly turned to issues such as human rights activism, the worldwide expansion of national human rights institutions, the gradual incorporation of women's rights, cultural and collective rights, and the diversity of local implementation practices. ${ }^{7}$ However, this expanding interest should not be confused with the development of a form of disciplinary consensus among sociologists. While some sociologists plead for a normative and political approach in the tradition of "public sociology," others argue that the sociology of human rights should strive for nothing but "systematically gathered, well-theorized and well-researched knowledge about social life." Nevertheless, what is certain is that human rights are no longer the sole domain of lawyers and political scientists but is a prominent issue on the research (and action) agendas for many different disciplines, including sociology. ${ }^{9}$

The work that is at the center of this essay, The Sacredness of the Person: A New Genealogy of Human Rights, by the renowned sociologist Hans Joas, illustrates many of these developments in the scholarship. This book is both an attempt to provide a distinctly sociological reading of the rise of human rights and an essay that seeks dialogue with other disciplines, notably philosophy and history, by devising a "historically oriented sociology." ${ }^{10}$ In this review essay we outline Joas's book and discuss its contributions to the developing subdiscipline of the sociology of human rights and human rights research more generally. We have structured this essay as follows. We first briefly outline Joas's approach to explaining the rise of human rights. We then turn to the key thesis underlying the book, namely, the social process of sacralization of human personhood. In a third section, we discuss one of the key contributions of the book: the analysis of how human rights are generated as universal values in reaction to violence and cultural trauma and thereby as experience of the sacred. In a fourth section we counter Joas's basic founding of human rights in culture by raising the question of human rights as legal rights and, thus, as politically and institutionally embedded rights. In the final part, we discuss the other key idea of the book, namely, the rise of human rights as a distinct process of value generalization all the way up to present time.

A Twin Approach to the Rise of Human Rights: Affirmative Genealogy and Sacralization

Human rights are often presented as the outcome of a long and noble maturation process of intellectual ideas such as freedom, equality, and human dignity—basically as the ultimate crystallization of Enlightenment ideas. ${ }^{11}$ The contemporary importance 
of human rights is then viewed as the outcome of the forward march of history, reason, and civilization, advancing the inherent rights and dignity of every person. In this vein, a large body of literature has focused on the precursors of human rights, claiming that the idea of universal human dignity and individual rights ultimately derives from, for instance, Catholic Christianity, Protestantism, or the French Enlightenment. These are the kind of narratives and histories that have been deeply criticized by Friedrich Nietzsche (and later Michel Foucault) because they misconstrue the past as a teleology leading to, and justifying, the current state of affairs. Nietzsche instead proposed a genealogical methodology, which gives credit to the contingent, unpredictable, hidden, and often dark currents of history. From this perspective, the job of the historian, sociologist, or philosopher is not to reconstruct the linear path from which human rights have victoriously emerged but to investigate the haphazard makeup of human rights, looking into the contingent conditions and unforeseen circumstances from which values grow.

In The Sacredness of the Person Hans Joas seeks to connect Nietzsche's awareness of historical contingency in the genesis of values with the more sociological question of why human rights and universal human dignity serve now as a new global culture and morality. Basically, how can we best describe and explain the deep moral commitment and almost universal appeal of human rights, functioning today as a de facto global civil religion with its own transnational symbols such as the Universal Declaration of Human Rights or shared rituals such as UN's Universal Periodic Review? However, in contrast to a Nietzschean reading, Joas does not want to criticize or deconstruct the idea of universal human rights. He thus devises both a research object and an approach that is not critical by conventional sociological measure but more geared to an interpretive approach. More precisely, while acknowledging that human rights are a genuine historical innovation, he also wants to preserve-and explain-the now self-evident moral character that human rights have for those who feel bound by them. By this preliminary methodological operation, he thereby distances himself from a critical study of human rights yet avoids engaging in the more moral philosophical debate on the justification of human rights. Moreover, this maneuver turns the analysis toward more of a sociology of ideas (the idea of human rights) coupled with a general analysis of sociocultural evolution.

Joas's key argument is that the commitment to universal values should be understood sociohistorically by focusing on the cultural and social conditions that enabled the idea of human rights to become a sacred symbol in the modern world. To this end, Joas intertwines two leitmotifs, a Nietzschean "affirmative genealogy" of the universality of human rights with a more sociological, Durkheimian idea of a longterm process of "sacralization of the person" underpinning the emergence of human rights in modern society. The marriage of these two rather different master ideas results in an original and subtle account of the emergence of the human rights ideal in modern society as a cultural transformation. Yet-as we will explain later-it also remains fraught with a certain tension between the grand sociohistorical narrative of the sacralization of human personhood and an emphasis on the contingencies and contradictions inherent in human rights. Moreover, this explicitly cultural approach has some problems coming to terms with the effect of the institutionalization and 
legalization of human rights and, thereby, examining the rise of human rights as not only a cultural transformation but also an institutional and societal transformation. These are sociological queries, combined with elements of a historical critique, animating the analysis we will pursue in the following. In the following subsections, however, we first focus on the master ideas directing the analysis, notably the thesis of the sacralization of the person.

\section{The Sacralization of the Person}

The key thesis underlying The Sacredness of the Person builds on the legacy of Émile Durkheim. Joas credits Durkheim as the first to consistently articulate the modern belief in human rights as an expression of a longstanding process of sacralization, "a process in which every single human being has increasingly, and with ever-increasing motivational and sensitizing effects, been viewed as sacred, and this understanding has been institutionalized in law." 12 Indeed, Durkheim was one of the first sociologists to rethink individual rights in a sociological way as a process in which godly powers have been relocated as authority immanent within society and eventually within the human person itself. In contrast with the established natural law thinking or liberal theory in the nineteenth century, Durkheim no longer saw rights as vested in individuals prior to and irrespective of their involvement in society but rather grounded them in an understanding of broader sociohistorical processes. What lies at the basis of individual rights, Durkheim wrote, "is not the notion of the individual as he/she is, but the way in which society treats and conceives, the esteem in which it holds the individual."13

Although Durkheim laid out the main contours of this process of increasing the value of the person, Joas adds important insights by examining a series of key sociopolitical and legal developments spurring this process, including the development of modern punishment, the abolition of slavery, and the codification of human rights in the Universal Declaration of Human Rights of 1948 (UDHR). Moreover, by drawing on-among others-Weber and Talcott Parsons, he examines the intellectual backgrounds to the cultural shift in the nineteenth and twentieth centuries leading effectively to a new sacredness of the person, of all persons. Joas concedes that the long process through which human personhood has become sacred has not been particularly linear or straightforward and that the sacralization of the person constantly had to compete (and still does) with other forms of sacralization, such as that of the nation or the classless society.

What is interesting in Joas's account of sacralization is his retour to the religious and deeply ambivalent origin of the term "sacred." From Durkheim onward, the anthropological and sociological tradition has understood the idea of the "sacred" in terms of "emotional ambivalence": to be sacred means to be set apart from everyday life, in such a way that this being-apart elicits fascination and enthusiasm as well as fear or even a form of abjection. The "sacred" hence became one term within a pair of contrasting ones, in which its counterpart is the profane. Sacred objects-such as the totems, crucifixes or, for that matter, human persons-are set aside from the everyday or profane and are forbidden ground, protected and defended by prohibitions.

Joas explicitly draws on Durkheim's famous interpretation of the human person 
as becoming sacred. "The human person," Durkheim wrote, "is conceived as being invested with that mysterious property which creates an empty space around holy objects, which keeps them away from profane contacts and which draws them away from ordinary life. And it is exactly this feature that induces the respect of which it is the object. Whoever makes an attempt on a man's life, on a man's liberty, on a man's honor inspires us with a feeling of horror, in every way analogous to that which the believer experiences when he sees his idol profaned." ${ }^{14}$

From this Durkheimian vantage point, Joas explains how the abolition of torture throughout the eighteenth and nineteenth centuries and the humanization of the criminal justice system can indeed be read as the outcome of an increasing "sacredness" of the human person. In line with previous work in cultural and legal history and sociology he describes how the elevation of the cultural ideal of "the human person" became visible in changing attitudes towards "bodily integrity," the increasing sense of the separation and sacredness of human bodies, which led to a humanization of penal law and penal practice. In contrast to Foucault, Joas does not interpret this humanization of penalization as a mere transformation of powerbecoming ever more dispersed and omnipresent—but as a first and fundamental step forward in the process of "inclusion" into the new category of the human being. Inclusion here means integration of those-slaves, criminals, handicapped people, and so forth—who had not been self-evidently included within humanity. The outward expansion of human rights in the twentieth century, in terms of both the range of claimants covered and the range of enforceable claims, can also be understood in these terms. Extensive rights for women, children, the elderly, sexual and cultural minorities, and people with disabilities were gradually put into place and also extended to noncitizen residents, as more and more often these rights were defined on universalistic grounds from which no "human beings" were to be excluded.

This retour to Durkheim's in some ways long forgotten thesis of the sacralization of the person for explaining the somewhat surprising success of human rights in the twentieth century raises the basic question of the actual explanative power of this idea for contemporary transnational society. The main analytical thrust of Durkheim's work and his interest in the sacred as a main sociological category was that every society has an aptitude "for setting itself up as a god or for creating gods." ${ }^{15}$ Secularized and individualized social orders also sacralize a culture's core, which in turn defines the social identity of a society and regulates the relationship between individuals and the community. In The Elementary Forms of the Religious Life, for instance, Durkheim noted how during the French Revolution "society and its essential ideas became, directly and with no transfiguration of any sort the object of a veritable cult ... things purely laical by nature were transformed by public opinion into sacred things." 16 In a Durkheimian account, the Declaration of Rights of Man and Citizen in 1789 can hence be read as an expression of a secular religion, institutionalized beliefs that are morally obligatory for all citizens. Interpreting the emergence of global human rights through a similar Durkheimian lens makes sense to the extent that it can relate the normative content of today's human rights standards to broader societal and cultural processes explaining the investment of sacrality in the human person (and Joas definitely heightens our understanding of these processes). The way we talk, think, and 
feel about torture, for instance, can easily be understood from a long-term cultural process to increasingly treat the individual body, at some level, as "sacred" in Durkheim's sense, as being set apart and not to be violated.

Likewise, the emergence of a global "human rights culture" with a strong emphasis on individual personhood can be interpreted from the worldwide diffusion of societal institutions that promote and manage "individuality" as something that needs to be societally developed (via mass schooling), protected (via welfare systems), and accounted for (via elections). It thus allows us to recognize the importance of secularization in relocating sacrality in everyday life from the religious realm of the gods to the secular realm of individual human activity, as expressed in the secular concept of the inherent "dignity" of the person, a sacred core of personhood that is no longer exclusively associated with high rank ("dignitas") but radically universalized. ${ }^{17}$ As Durkheim claimed was true of religions in general, the "cult of the individual" whether in its more traditional, religious form (expressed in the idea of the "soul") or in its secular form (expressed in human rights and the "inherent dignity or worth of the human being")_-allows the global, individualized society to symbolize or visualize itself in a sanctified self-image that contracts the sacred on the abstract, modern man. ${ }^{18}$

Yet while a Durkheimian perspective may be useful to understand the emergence of a human rights culture and the diverse societal processes explaining the investment of sacrality in the human person, the sociological concept of the sacral is barely helpful to explain how human rights developed as a politico-legal institution in modern transnational society. During the last decennia, human rights discourse has become the preferred moral language of not only world culture but also of global governance, decisively shaping political, legal, and economic practices. A Durkheimian framework, grounded in a religious interpretation of the sacred, has no real vocabulary for treating this politico-legal dimension of human rights. Furthermore, its focus on the functional and consensual aspects of religion—and this goes for Joas's analysis as well—has a tendency to deflect attention from the continuous symbolic struggles and power conflicts surrounding human rights. It can be argued that a fuller account of the sacred requires more attention to the operation of power.

It might be illustrative at this point to compare Joas's Durkheimian reading with Giorgo Agamben's famous interpretation of the sacred as a critical juridico-political category. ${ }^{19}$ Agamben shares with Joas the view that the notion of the sacred is crucial for understanding the contemporary position of human rights, yet he construes it as a much more dystopian notion. Agamben's starting point is different; in contradistinction to the tradition of anthropology and sociology he claims that the idea of the sacred has a legal, not a religious, origin. ${ }^{20} \mathrm{He}$ derives his concept of the sacred from an archaic Roman law concerning the homo sacer, whereby someone or something is declared to be sacred (sacer esto) by excluding it from the protection afforded by the law, thereby separating from the context of human life a rest of life, which he calls "bare life." Characteristic for the homo sacer is that he is abandoned, set apart by power in the sense that the polity no longer has an interest in him; he's no more than "bare life" that can be killed with impunity. "What defines the status of homo sacer," Agamben writes, "is therefore not the originary ambivalence of the sacred that is assumed to belong to him, but rather both the particular character of the double 
exclusion into which he is taken and the violence to which he finds himself exposed." ${ }^{21}$ The double exclusion Agamben here refers to is exclusion from not the profane Roman law (ius humanum) but also religious law (ius divinum); "while it's forbidden to violate the other sacred things, it is licit to kill the sacred men." ${ }^{22}$ What is crucial for Agamben is that this figure of double exclusion also typifies the structure of sovereign power, which exactly defines itself by its capacity to exclude some part of human life from civil or political society and open it up to violence, to create "a zone of indistinction between inside and outside, chaos and the normal situation - the state of exception" where human beings can be killed with impunity. In our contemporary world, Agamben's homo sacer is exemplified by the legal limbo in which many refugees or asylum seekers find themselves, discourses of moral cosmopolitanism notwithstanding. In contrast to citizens, "aliens never quite reach the position of comfort allotted to them" by postnationalists and human rights discourse. ${ }^{23}$

Agamben's reading thus exemplifies how the process of sacralization of the person is from the start intertwined with the workings of sovereign power. While Joas sees the sacredness of individual life as a fundamental feature or "right" of the person that can be invoked in opposition to sovereign power, Agamben in Homo sacer asserts that the sacred in its originary sense is a function of the sovereign power of the state. Agamben's suggestion is precisely that the law, and in particular human rights law, is capable of capturing and controlling the life process only by making life into something sacred. The right to life that is associated with the idea of "sacred life," and which gives the ultimate justification to any sovereign power, in reality signals that life has already been captured by sovereign power and is at its mercy: "The spaces, the liberties, and the rights won by individuals in their conflicts with central powers always simultaneously prepared a tacit but increasing inscription of individual's lives within the state order, thus offering a new and more dreadful foundation for the very sovereign power from which they wanted to liberate themselves." 24

The consequences that can be drawn from Agamben's reading of the sacred for the interpretation of contemporary human rights are, evidently, very different from those that Joas draws. While Joas sees contemporary human rights as the culmination of a long process of societal inclusion and universalizing a person's worth, Agamben stresses the liminal, ambiguous, and often dark character of human rights, which irrevocably bear the mark of sovereign power. By sacralizing bare, unqualified life-and this is probably the most polemical thesis in Homo Sacer-the human rights movement separates the human from wider political and communitarian questions "and therefore, despite themselves, maintain a secret solidarity with the very powers they ought to fight." 25 From Agamben's point of view the emergence of human rights hence signals the crisis of the nation-state and the concomitant impotence of the international system to provide universal protection for individuals. From the point of view of Joas - who does not refer to Agamben even once-such a dystopian reading of human rights would probably be disqualified as it fails to appreciate the fact that human rights are not primarily about some cadaveric "bare life" but rather about the protection of individual moral agency. Homo Sacer clearly shows, however, the limitations of reading the sacred in complete disconnection from the operation of (state) power. 


\section{Violence, Cultural Trauma, and Human Rights}

The part of The Sacredness of the Person in which the connection between the sacred and power is most present-in our view also the strongest part of the book-is Joas's sociological reflection on how collective experiences of grave injustice and violence can initiate societal change (without, however, directly translating into legal reform). For this, he again returns to the ambivalent Durkheimian meaning of the term "sacral," connecting moral enthusiasm to the experience of fear, horror, or "tremens." A deeply felt commitment to values such as the sacredness of the living human body does not grow out of Habermasian rational consideration, Joas emphasizes again and again. Experiences of horror and violence are the real driving forces in history. The main questions that Joas poses concern the role that violence has played in the history of human rights and how it is possible to translate these experiences into a value commitment to universal human dignity.

Of course, the literature on human rights has often pointed out the link between human rights violations and war, genocide, and other atrocities. The abolition of torture has been viewed as a watershed in the development of individual human rights. The decisive historical moment for the internationalization of human rights is usually considered World War II, when the link between collective violence and human rights became clearly visible and, shortly after, when the Nazi and Japanese atrocities led to worldwide condemnation embodied in the international war crimes tribunals of Nuremberg and Tokyo. Also today, the literature on human rights is replete with language discussing human rights violations in terms of "violence" against the boundaries of the self (for example, female circumcision) or in terms of "victims" who are excluded or abused against their will (for example, migrant workers). Yet Joas adds to this discourse by spelling out the preconditions for the successful transformation of experiences of violence into a commitment to human rights. Cruelty, suffering, and bondage are not sufficient to transform negative experiences into universalist values and norms. In fact, human history is packed with cases of collective violence that have not led to progress in human rights (the crimes of Stalinism, to give but one example). The question that arises then is why and when a process of coming to terms with traumatic experiences of collective violence can take place. By what mechanisms do violent experiences ranging from rape to paramilitary death squads or genocide become embodied into norms, practices, and institutions expressing moral universalism?

Joas develops an answer by putting forward a conceptual triangle, which he immediately applies to the most important human rights movement of the nineteenth century, abolitionism (the movement to abolish slavery). First, a framework of discursive traditions has to be available and deliver moral standards by which existing practices are to be condemned. In the case of the genesis of abolitionism, it became possible to regard a prevailing practice such as slavery as a sin only because a universalist morality—extending to "the least of my brothers" — was already inherent in Christianity. The abolitionist movements in Great Britain and the United States were indeed supported mainly by evangelical religious groups who condemned slavery (in the seventeenth and eighteenth centuries applied mostly to Africans) as "un-Christian" 
and scandalized the opposition of slaveholders to the evangelization of the slaves. Yet it took a specific historical conjuncture to put such universalist moral schemes into practice. Although an intense moral motivation to extend rights to slaves was present in Protestant culture, it required, second, some sociostructural changes to make the inclusion of slaves into humanity meaningful in the societal context of that time. As Thomas Haskell has famously pointed out, it was only because of the rise of worldwide industrial capitalism and the increasing global interconnection of social relations that a "humanitarian sensibility" became possible. ${ }^{26}$ It was primarily a change in cognitive style - specifically a change in the perception of causal connection and consequently a shift in the conventions of moral responsibility so that we feel responsible for misdeeds elsewhere- that underlay the new constellation of attitudes and activities that we now group under the banner of human rights. "Together," Joas writes, "the first and second components open up a space in which it becomes possible to articulate experiences that previously went unheard." ${ }^{27}$ Yet still a third component was needed for the abolitionist movement to become politically successful. Without the creation of a public sphere going beyond the borders of the nation-state and a network of activists operating on a transnational basis, abolitionism would never have succeeded in reframing slavery from a legitimate or necessary economic activity into a serious violation of individual human rights.

This threefold scheme allows Joas, in principle, to move beyond the traditional intellectual history of human rights. Although intellectual traditions containing universal values and ideas, such as the Christian heritage, are a crucial precondition for the rise of human rights, their actual unfolding into obligatory norms and values requires appropriation by actors in specific sociostructural circumstances. Joas's book is very strong in explaining how semantic traditions and cultural sources are reinterpreted into the modern value system of universal human dignity. Yet it is rather weak in elaborating the mechanisms through which traumatic experiences of violation of this dignity are effectively transformed into politico-legal norms (the third component, so to speak). Joas provides the reader, for instance, with a brilliant reading of how the Christian concept of the immortal soul of every human being as her or his sacred core has slowly been transformed into the concept of the self as used today by psychologists and sociologists. Yet why and how this modern self has become the focal point of an array of international legal entitlements is hardly clear. The case of the abolition of slavery also demonstrates that the moral and religious commitment to abolish slavery did not automatically lead to further legal progress. The abolitionist movement was crucial for identifying a societal injustice but did not do much to set up appropriate legal standards for fully eliminating slavery and guaranteeing equal rights. In fact, it took the (largely) black civil rights movement in the sixties to break the Jim Crow laws, improve the positive legal status of African Americans, and realize the guaranteeing of specific rights such as education (equal access to schools and universities), suffrage, and so forth.

In other words, Joas's "new genealogy of human rights" improves our insights about the "human" of human rights, the more or less concrete sense of a globally enlarged morality accompanying the institution of human rights, but conveys very little about human rights as a legal category. It is true, as we will discuss below, that 
Joas does have a chapter on the UDHR. Even so, the crucial question of why and how the modern ideal of universal human dignity has been institutionalized or codified into universalistic legal codes and norms is hardly taken up in this book, which poses a real problem for a sociology of human rights.

\section{Human Rights as Legal Rights}

As already indicated, it is our claim that the contemporary cultural power of human rights lies to a certain extent in their rhetorical ambiguity and oscillation between the multiple registers of law and morality. ${ }^{28}$ The claim that "asylum seekers have a right to mobility," for instance, not only refers to normative claims or aspirations but simultaneously calls for legal change and codification, and for political institutions of oversight, regulation, and enforcement. Put differently, the higher status of human rights is not only a question of grounding them into cultural value commitments but is also a matter of legal and political institutionalization and the societal changes resulting from this. ${ }^{29}$ One may even argue, as Hannah Arendt famously did, that only legal human rights offer the minimum recognition of abstract humanity and can thus be considered more fundamental than cultural ideals of universalized human dignity. ${ }^{30}$ Arendt's writings are above all a firm reminder that human rights have concrete meaning or deliver effective protection only when they are backed up by public institutions, most obviously the state, including legislatures, courts, schools, and hospitals but also a host of concrete judicial and administrative practices. ${ }^{31}$ Consequently, human rights are only "real" to the extent that they are protected—or violated—in concrete social locations: in a prison or government office, at home or in the workplace. Being neither entirely legal nor ideational, human rights are above all an integral part of the mundane societal fabric in its many and overlapping fields of practice. Or, as we have suggested elsewhere, they must become socially institutionalized and embedded, not only in people's mindsets and orientations but as well in the day-today workings of societal institutions such as the judiciary, the schooling system, healthcare, and the family. ${ }^{32}$

However, as Joas decidedly focuses on the broader sociohistorical processes through which justification of human rights becomes possible in this first place, it might seem unfair to criticize him for devoting so little attention to the actualities of the legal and political practices working out this idea of rights. Yet decoupling the analysis of sacred human dignity from their embodiment in international and local legal norms, concrete democratic procedures, or, say, cultural gender schemata preventing domestic violence imparts a kind of aloof abstractness to his human rights thought. It may in fact contribute to the perception that our cultural understanding of humanness has little to do with the mundane practices of administration, work life, or providing such basic needs as food and housing, and that the law needs to respond only when those highly valued entitlements are threatened by force. That would obviously be a huge underestimation of the task of making human rights a reality. This not only requires a commitment of journalists, bureaucrats, and politicians to prioritize human rights language in their thinking, writings, and other actions. It also 
includes a second, more complex task, "requiring tens of millions of state and parastatal agents— judges, police officers, bureaucrats, soldiers, and paramilitaries— to change their daily routines." 33

While Joas obviously would not argue against this, he nevertheless seems to operate with a tacit understanding that morality gets easily translated into laws and legal practices. Yet the legal system—as Niklas Luhmann has repeatedly pointed outcannot function simply on the basis of moral concepts such as universalized human dignity. The law can only incorporate moral principles or value-commitments by recoding them as legally relevant information, under specific legal conditions, in order to establish whether something counts as legal or illegal at a specific place and time. Law refrains generally from positing universally valid moral commitments and instead adopts provisionary verdicts that may be revised at a later point in time. Since the logics of moral and legal reasoning clearly relate to different worlds, meaning different subsystems of society, the effort to translate moral considerations into legal cases is often slow, complicated, and frustrating, which of course contributes to the politicomoral contestation and confusion that so often accompany human rights issues. Jeremy Waldron makes a different but comparable critique, by analyzing dignity as a status idea, not a value idea, whereby he highlights the key role of law in promoting and elevating dignity. ${ }^{34}$ In other words, according to Waldron, dignity is primarily constituted and vindicated by legal systems. Joas's book generally fails to account for any of these workings of law with respect to human rights. As a consequence his account is strangely detached from the day-to-day social level of human rights, something seemingly central to any sociology analysis of human rights.

\section{Human Rights and Value Generalization}

Joas does, however, provide a very interesting analysis of how contested values are eventually transformed into the idea of human rights, yet without following through and explaining how the idea is translated into legal and institutional practices. Certainly, disagreement about values is rife in a world of different and contradicting moral and religious belief systems. Since the religious wars of the seventeenth century and the Protestant Reformation had destroyed the illusion of a unified religious (Catholic) world, fundamental and human rights have often been viewed as delivering an overarching, more abstract set of moral convictions and principles. Human rights and freedoms such as the freedom of conscience or expression are frequently invoked to demand religious tolerance and to judge moral systems on their degree of humanness. Human rights are then seen to provide more generalized values beyond the specifics of different religions and worldviews-above all the value of the person as a human being in his or her own right. In the last chapter of The Sacredness of the Person, Joas does build on such a line of thinking by taking up Talcott Parsons's concept of value generalization and applying it to the genesis of the Universal Declaration of Human Rights.

For Parsons, the concept of value generalization had to be viewed in the context of increasing societal differentiation. It is a cultural response to the increasing and divisive societal differences that derive from the increasing division of labor and an 
internal functional differentiation of modern society into different autonomous subsystems (the economy, science, politics, law, and so forth) with their own logics, preferences, and steering media (money, power, truth, and so forth). From this perspective human rights appear as a more abstract, more generalized type of morality that "is couched at a higher level of generality in order to ensure social stability." ${ }^{5}$ Only by constituting a generalized cultural framework in which societal and individual diversity is permitted, defended, and even promoted can the multitude of different moral and religious belief systems be contained. A quasi-religious commitment to the value of the person is a crucial element of this generalized cultural framework. Of course, this way of thinking about overarching values in a differentiated society echoes some of the key ideas of Durkheim, and this part of Joas's argument does also fit nicely with the earlier, more Durkheimian parts. Moreover, by comparing Rawls's analogue philosophical concept of an "overlapping consensus," Joas rightly points out that Parsons's sociological conception entails more than "merely a decision to embrace peaceful coexistence despite insurmountable value differences"; it rather aims to describe the process of mutual communication about values, through which values can be modified and renewed. ${ }^{36}$

Interpreting Parsons's concept of value generalization in this way allows Joas to put forward the thesis that the genesis of the UDHR can be best understood by reading it as a process of coming to agreement on common value-commitments, beyond the specifics of the different religious, philosophical, and political traditions involved in the drafting of the Universal Declaration. Moreover, Joas argues that combining this analysis with his overall thesis of the process of the sacralization of the person allows for synthesizing the existing historical knowledge of the drafting of the UDHR. This is, of course, a big claim and one that is unfolded against the background of what historians probably would consider a rather cursory reading of historical sources; historical sociologists would equally be critical of his choice of fairly limited material. Joas does modify the claim somewhat by pointing out that his analysis concerns primarily how fundamentally different values—and "sacralities" potentially can be reconciled. ${ }^{37} \mathrm{He}$ limits the analysis to three key dimensions: the background to the UDHR and its relation to World War II and particularly Nazism; the collective enterprise through which the document was produced; and, finally, the specific window of opportunity in which the UDHR was drafted. These three dimensions in different ways relate to the well-known claims made by Susan Waltz on the four persistent myths of the drafting of the UDHR: that it was (I) a reaction to the Holocaust; that (2) the great power of the United States, the United Kingdom, and the Soviet Union did most of the work; that (3) a single individual was the main author; and that (4) the success of the Declaration was due to the United States. ${ }^{38}$

\section{The Universal Declaration of Human Rights in Sociological History}

Generally, Joas supports Waltz's analysis and provides his own deconstruction of all four myths of the UDHR with the goal of exploring the three dimensions identified above. At some points, however, he takes up debates that have long been ended. For example, few today will question that the movement for international human rights dates back further than the drafting of the UDHR and that, for this reason, the 
Declaration cannot solely be explained as a reaction to the horrors of World War II. Yet most acknowledge that the immediate postwar period opened a unique window for achieving the UDHR, a project that was already well underway before and during the war. Joas's point, although brief, is different and is aimed at countering a number of historians who recently have made two controversial claims, namely, that human rights discourse seemed to disappear in the nineteenth century and that human rights were not part of the development of the notion of self-determination and ultimately decolonization. ${ }^{39}$ While the latter argument is already countered by a number of other authors, it is clearly more of a fundamental challenge for Joas's analysis if we were to generally exclude the nineteenth century from the modern history of human rights. ${ }^{40}$ It would basically render Joas's analysis close to meaningless.

We do generally agree with Joas that, at least from a historical sociological perspective, it seems questionable to exclude such key periods and developments from the structural history of human rights, that is, human rights as a set of long-term processes of social structuration produced by interplays at the level of agency and contingent on broader societal developments. Quite clearly, as also documented in Joas's book, human rights were seriously debated in the nineteenth century in both sociology and law-Joas's key examples being the brilliant works of Durkheim and Georg Jellinek. A basic analysis of Google Books published in English would also strongly indicate-with the necessary caveats — that both civil rights and human rights were indeed written about during the period. Of course, civil and political rights unsurprisingly have a higher score around the revolutionary years of the $1840 \mathrm{O}$ - the so-called Springtime of Nations - and, then, a slight dip toward the end of the century, yet they never seriously disappear. The evolution of the term "rights of man" importantly follows the exact same pattern. Critical historians of modern human rights would counter this by drawing a distinction between civil and political rights and modern-day universal human rights, at the time the closest concept being the rights of man (les droits de l'homme, Menschenrechte, and so on). ${ }^{41}$ The main conceptual difference is the universality and somewhat international aspirations of the rights of man compared to basic civil and political rights that, in some cases, were guaranteed by national constitutions in Europe in the nineteenth century. ${ }^{42}$

While there is an obvious historical truth to pointing to the, by contemporary standards, rather limited role of human rights in the nineteenth century, the argument does not necessarily undermine Joas's attempt at a sociological genealogy of human rights. ${ }^{43}$ As outlined above, his objective is to combine an awareness of historical contingency with respect to the genesis of values. If we look at the production of values in historically highly contingent contexts of the late nineteenth century, we find vivid examples of the processes that Joas has in mind in, for example, France. Events such as the Dreyfus affair were important moments for human rights culturally, politically, socially, and even legally and triggered, for example, the creation in 1898 of the Ligue des Droits de l'Homme, which became a pioneering international human rights non-governmental organization by the I920s. ${ }^{44}$ Moreover, the Dreyfus affair also contributed to the creation of the notion of the public intellectual as a defender of principles, as argued by the historian Christophe Charle, again a development of key importance for modern-day human rights activism and its 
institutionalization. ${ }^{45}$ To put it differently, nationalism did not eliminate human rights as claimed by some; instead it intensified the battle over human rights and made it partisan in a new way that again fueled the process of articulating human rights and even the idea of sacredness of the person as shown by Joas. However, this does not imply that there is by definition a strict causality between such individual events and the articulation of universal human rights in 1948 - or the breakthrough of human rights in the I970s; but they all contributed to the categorization of a subject and the identification and valorization of a struggle that undoubtedly impacted subsequent developments in various ways.

The linkage between self-determination and human rights is in some ways central to modern human rights if we follow a similar logic of structural inquiry. While it is undoubtedly true that many Third World leaders, particularly in the 1950s and 1960s, framed their advocacy in other terms than human rights, such an analysis tends to overlook how many agents from metropolitan areas engaged in the very same fights under the banner of human rights. In these contexts, it is not fruitful to attempt to distinguish human rights as a singular catalyst for independence in a strict causality argument, but it is, conversely, problematic to simply leave them out of the picture as recently suggested by some historians. With regard to both nineteenth-century human rights discourse and practice during decolonization, there is sociologically speaking a relative social continuity at the structural level in the battle over human rights. What there is not, and Joas would agree, is a teleology in the development of human rights. But those are two different issues that often are confused in the debate. The key point we are making in favor of a structural historical sociological reading of human rights can best illustrated by the Max Weber's classic analysis of the relationship between Protestant ethics and the capitalism. ${ }^{46}$ While Weber relates the social practices of puritan Protestantism to the success of capitalism in certain regions, he is not claiming that the spirit of Protestantism is directly intending the construction of capitalism. The analytical take-away is precisely that there is no need for explicit intention for having a social consequence. Basically, just as abolitionists were driven by Protestant ideas, they might, as Joas suggests, have had a structural effect on the idea of the human being, which subsequently impacted the development of human rights. Likewise, even if revolutionary African leaders did not use the rhetoric of human rights for a number of reasons, it is sociologically unsustainable to make a general claim that their practices therefore cannot be part of the structuration of human rights and, thus, its genealogy and history.

\section{The Universal Declaration as Process of Value Generalization}

Joas is, however, trying to make another point, namely, that human rights already in the nineteenth century had diffused across the globe to Asia, Latin America, and Africa and, consequently, that the Europeans and North Americans could not present themselves as the "true authors" of the concept at the negotiation of the UDHR. This is again a big claim and one that might have deserved a lot more empirical substantiation. In his defense, Joas mainly wants to argue that if human rights were already polyglot in the early twentieth century, it is logically indefensible to maintain either 
the myth of Western hegemony or of René Cassin as the main author of international human rights in the aftermath of World War II. Let's take the latter first.

To be sure, very few would today claim that Cassin played such a singular role. But to argue, as Joas does, that Cassin had no real competences or ideas with regard to human rights besides practical skills as "logical systematizer" of law is missing the point and unduly downplaying both Cassin's level of knowledge and engagements in French and international law and politics throughout the interwar period and during the war. ${ }^{47}$ Although Cassin might have been a hypocrite in his simultaneous defense of human rights and rejection of a broad right to self-determination, he was certainly well equipped to take part in the drafting, and probably better equipped than many of the other actors. Moreover, he certainly came to the negotiation with an idea. As shown by Jay Winter and Antoine Prost, one of his roles for the government of Free France in 1942 was precisely to establish a commission that prepared the French voice for the post-World War II politics of a new world order in which human rights played a central role. ${ }^{48}$ For this purpose the commission drew on the insights of eminent French intellectuals of the period, among them Jacques Maritain. Hence, unless one assumes that the drafting of the UDHR was carried out in a void of international legal knowledge, Cassin's legal background gave him some obvious advantages together with the other lawyers involved (for example, Hernán Santa Cruz and John P. Humphrey). Another element worth emphasizing is that the competing authors from non-Western countries were strikingly cosmopolitan and educated at elite Western universities (for example, Charles Malik and Pen-Chun Chang). Even if a certain global value-generalization did take place, it is probably better described as more of a cosmopolitan convergence and one that in fact quite carefully abstracted from the underlying conflicts of values. Cassin, if his biographers are to be trusted, would very much have felt at ease in such a milieu. He had after all been a regular at the League of Nations since the rig2os and was very well connected in the world of international law and politics. And he certainly had a taste for grand ideas.

This brings us to the other question: the relative authority exercised by the great powers over the proceedings. While we would generally agree with Joas that none of the major powers had real interests in lifting human rights to a higher international legal plane-Britain and France for mainly late colonial reasons, the United States and the Soviet Union for immediate geopolitical reasons-the fact that the UDHR was drafted in the French style of a declaration rather than the British tradition of a bill of rights is in itself sociologically interesting for exploring both its value-generating effects and the more discreet exercise of power. We would generally posit that the two dimensions must be analyzed as two sides of the same coin if one is to understand the proceeding and its results. In his seminal work on European human rights, Brian Simpson has interestingly argued that the British left the UDHR unsatisfied, having indeed prepared a draft international bill of rights, and instead turned to the European Convention of Human Rights for realizing international human rights. ${ }^{49}$ This question of the legal nature of the Declaration was more generally of importance as it was, after all, easier to agree on a non-legally binding international document than a binding one. Joas does of course accept this, but his analysis does not reflect on it 
sufficiently as he seems too focused on demonstrating how a cross-cultural value generalization has taken place, even if he hints that most of the major players had already decided that the outcome of the proceedings was not only of limited interest but in fact should be restricted.

All of this comes down again to a basic sociological question of the relationship between values as more abstracted norms and values as practiced norms, legally or otherwise, and ultimately power. Informed observers were well aware of the problem of creating too great a discrepancy between the idea of universal human rights and the legal protection of human rights in the mid-I940s. A key international lawyer of the period, Hersch Lauterpacht, made a strong plea for legally substantiating international human rights in 1945 . We quote him at length as he makes the point absolutely clear:

Should it be decided to reduce any international bill of human rights to a mere statement of political or moral principle, then, indeed, it would be most likely to secure easy acceptance; any possible difficulty in agreeing upon its terms will be merged in the innocuous nature of its ineffectual purpose. But if the [S]econd World War ought to end, then a declaration thus emaciated would come dangerously near to a corruption of language. By creating an unwarranted impression of progress it would, in the minds of many, constitute an event which is essentially retrogressive. For it would purport to solve the crucial problem of law and politics in their widest sense by dint of a grandiloquent incantation whose futility would betray a lack both of faith and of candour. ${ }^{50}$

In this light, the cosmopolitan club in charge of drafting the UDHR come across as only slightly more effective than their philosophical counterparts at the UNESCO who, as noted by Joas, wrote a report on the foundation of human rights that even the drafters of the UDHR chose to ignore. ${ }^{51}$ Our point is that the power exercised by some of the major powers_-for each of their individual reasons — greatly impacted the actual proceedings and to a large extent explain the relatively minor importance of the UDHR in its time. In that sense, it was a success for those countries that sought to minimize its impact.

Of course, international documents tend to take a life of their own post-drafting and sometimes with little reference to their genesis. ${ }^{52}$ If one were to analyze the "valuegenerating" effects of the UDHR, we would argue that one would have to look a great deal beyond the UDHR. Joas does very briefly mention this toward the end of his book, but his analysis of how this initial cosmopolitan accomplishment is subsequently turned into binding international law is much too brief and once again fails to deal with the complexities of the sociology of (international) law and seems to introduce the kind of teleology that his analytical model is precisely set up to avoid. The subsequent story is, of course, fairly well known, even if there is still much work for historians and social scientists to be done. First, the utopian moment that led to the UDHR did not last long and the declarative contents of the UDHR were quickly split into two different covenants. Fueled by Cold War rivalries, the logic of opposing civil and political rights and social, economic, and cultural rights thus entered the carefully crafted cosmopolitanism of the UDHR. Second, when the covenants were eventually applicable as international law in the 1970s, the world was a relatively 
different place. ${ }^{53}$ This is not to claim that the UDHR had not clearly enabled some of these subsequent developments and sown some important seeds, but the outcome was highly contingent on subsequent sociopolitical and cultural developments. Joas would of course not disagree with this, but we will disagree with Joas on how much this sociopolitical and legal process of realizing values as practiced and institutionalized norms should feature in an analysis presenting itself as the sociological genealogy of human rights.

\section{Conclusion}

Our general disagreement with Joas on the relationship between more abstract values and practiced and institutionalized norms owes to a degree to some underlying sociological differences, which nevertheless have real impact on our understanding of human rights. While we both insist on the importance of long-term social processes for explaining the power of human rights in contemporary society, we do this is in very different ways. Joas is interested in it with regard to reforming the idea of the person-the rise of the person as a new sacrality and cultural transformation. In all fairness our emphasis is on the impact of human rights on the institutions of modern society and the power they exercise from that vantage point, that is, what makes them "real." From our perspective, it is doubtful whether Joas can explain the transition from values to legal institutions and more generally societal norms. Joas's analysis, as particularly suggested in the discussion of his treatment of the UDHR, lacks empirical detail (and sometimes accuracy) for convincingly explaining the interplay of macroand micro-transformations in the production of a cross-cultural text. To some extent this is due to the rather implicit notion of power that Joas deploys throughout the analysis. Even if his three-fold scheme of discursive traditions, socio-cultural changes, and transnational operation provides an interesting analysis of the movement to abolish slavery and allows him to challenge more traditional intellectual history of human rights, it is still lacks a fourth dimension that explains more specifically how the power was exercised. Basically, it provides a great reading of the conditions enabling the process but too little on how those sociocultural conditions were exploited in the concrete manufacturing of a new policy and ultimately legal stance on slavery. This would have made the analysis far more convincing, as it would have allowed for considering the peculiar historical contingencies of these developments with respect the broader idea of human rights. It is precisely this criticism we also raise against his analysis of the drafting of the UDHR.

Our critique relates to parallel debates in the discipline of history launched as to whether human rights really played a role in, for example, the abolitionist movement or, later, in the decolonization movements- or whether these processes easily could have unfolded without a reference to human rights. To paraphrase Stefan Ludwig Hoffmann, can we understand human rights as the unpredictable results of political contestations rather than the result of conscious construction? ${ }^{34}$ Joas's goal is, however, not to answer this question, as it seems to introduce a too dramatic opposition between teleology and contingency. As a sociologist, his goal is to understand how the idea of the sacred person increasingly penetrates the construction of modern society 
and, thereby, helps pave the road for modern universal human rights. Yet his Durkheimian focus on the functional and consensual aspects of the sacred draws attention away from the symbolic struggles and power conflicts surrounding human rights and is hardly helpful to explain the development of human rights as a legal institution.

Regardless of the criticisms we raise, there is little doubt that Joas has grounded human rights in an interesting and compelling story about the increasing sacrality of the human person in modern world culture in a highly readable and provocative book. His treatment of Durkheim, Parsons, and even Jellinek is exemplary and demonstrates a very high level of sociological analysis. Although historians will probably accuse him of using rather sweeping historical statements, his approach helps him identify something else-a different object in human rights—-that often is lost in historical detail, namely, the construction of the person as a sacred object in a long-term societal process underlying the emergence of a human rights discourse that has achieved an unparalleled moral status around the world. By virtue of his analysis, the road is paved for other sociologists to show how human dignity in some instances gets translated or embodied into legal norms - and in many others, remains a rather empty claim with very little impact on the day-to-day practices of human rights. In this light, his analysis comes as a very welcomed addition to the growing subfield of the sociology of human rights, and it should also make historians reconsider their own at times rather sweeping statements of the causality of the development of human rights.

\section{NOTES}

I. On the usefulness of a sociological perspective on human rights, see Gideon Sjoberg et al., “A Sociology of Human Rights," Social Problems 48, no. I (February 200I): II-47; Bryan S. Turner, "Outline of a Theory of Human Rights," Sociology 27, no. 3 (August 1993): 489-512; Mathieu Deflem and Stephen Chicione, "The Sociological Discourse on Human Rights: Lessons from the Sociology of Law," Development and Society 40, no. I (June 20II): IOI-I5.

2. Mikael Rask Madsen and Gert Verschraegen, "Making Human Rights Intelligible: An Introduction to Sociology of Human Rights," in Making Human Rights Intelligible: Towards a Sociology of Human Rights, ed. Mikael Rask Madsen and Gert Verschraegen (Oxford: Hart, 2013), $\mathrm{I}-2$.

3. Ibid., 2.

4. Margaret R. Somers and Christopher N.J. Roberts, “Toward a New Sociology of Rights: A Genealogy of 'Buried Bodies' of Citizenship and Human Rights," Annual Review of Law and Social Science 4 (December 2008): 387.

5. Patricia Hynes et al., "Sociology and Human Rights: Confrontations, Evasions and New

Engagements," International Journal of Human Rights I4, no. 6 (November 2010): 8I2.

6. Bryan S. Turner, Vulnerability and Human Rights (University Park: Pennsylvania State University Press, 2006), and Anthony Woodiwiss, Human Rights (London: Routledge, 2005).

7. See, for example, Judith Blau and Mark Frezzo, Sociology and Human Rights: A Bill of Rights for the Twenty-First Century (London: Sage, 20Io); Mikael Rask Madsen, La genèse de l'Europe des droits de l'homme : Enjeux juridiques et stratégies d'Etat (France, Grande-Bretagne et pays scandinaves, 1945-1970) (Strasbourg: Presses universitaires de Strasbourg, 2010); Rhiannon Morgan and Bryan S. Turner, eds., Interpreting Human Rights (London: Routledge, 2009); Lydia Morris, 
Asylum, Welfare and the Cosmopolitan Ideal: A Sociology of Rights (London: Routledge, 2010); Kate Nash, The Political Sociology of Human Rights (Cambridge: Cambridge University Press, 20I5).

8. For a good example of a normative and political approach to human rights, see Judith Blau and Alberto Moncada, "In Defence of Societies," in Making Human Rights Intelligible. For a plea for value-free sociological research, see Deflem and Chicione, "The Sociological Discourse on Human Rights," II3.

9. Michael Freeman, Human Rights: An Interdisciplinary Approach (Oxford: Polity Press, 2002).

Io. Hans Joas, The Sacredness of the Person: A New Genealogy of Human Rights, (Washington, D.C.: Georgetown University Press, 2013), 2.

II. For critiques in history and sociology, see, for example, Stefan-Ludwig Hoffmann, ed., Human Rights in the Twentieth Century (Cambridge: Cambridge University Press, 20II); Mikael Rask Madsen, "Reflexivity and the Construction of the International Object: The Case of Human Rights," International Political Sociology 5, no. 3 (September 201I): 259-75; Samuel Moyn, The Last Utopia: Human Rights in History (Cambridge, Mass.: Harvard University Press, 2010).

I2. Joas, The Sacredness of the Person, 5 .

13. Emile Durkheim, Leçons de sociologie (Paris: Presses Universitaires de France, 1950), 93.

I4. Emile Durkheim, "Individualism and the Intellectuals," in Durkheim on Religion, ed. W. S. F. Pickering (London: Routledge, 1975), 61.

15. Emile Durkheim, The Elementary Forms of Religious Life, trans. Joseph Ward Swain (New York, Macmillan, 1915), 245.

I6. Ibid., 245 .

17. Jeremy Waldron, “Dignity and Rank," European Journal of Sociology 48, no. 2 (August 2007): 20I-37.

18. See also James V. Spickard, "Human Rights through a Religious Lens: a Programmatic Argument," Social Compass 49, no. 2 (June 2002): 227-38.

19. Giorgo Agamben, Homo Sacer: Sovereign Power and Bare Life (Stanford, Calif.: Stanford University Press, 1998).

2o. Ibid., $75-80$.

2I. Ibid., 82 .

22. Ibid.

23. Christian Joppke, Citizenship and Immigration (Cambridge: Polity Press, 20I0), 84

24. Agamben, Homo Sacer, I2I.

25. Ibid., I33.

26. Thomas Haskell, "Capitalism and the Origins of Humanitarian Sensibility, Part I," American Historical Review 90, no. 2 (April 1985): 339-6I; Thomas Haskell, "Capitalism and the Origins of Humanitarian Sensibility, Part 2," American Historical Review 90, no. 3 (June 1985): 547-66.

27. Joas, The Sacredness of the Person, 92.

28. Mikael Rask Madsen, "La fabrique des traités européens: Une analyse de la genèse et évolution De la Charte des droits fondamentaux," Revue française de science politique 60 (April 20IO): 27I-94; Madsen and Verschraegen, Making Human Rights Intelligible; Gert Verschraegen, "Human Rights and Modern Society: A Sociological Analysis from the Perspective of Systems Theory," Journal of Law and Society 29, no. 2 (June 2002): 258-8I.

29. See also Jeremy Waldron's exploration of human rights, dignity, and morality in which 
he equally makes the claim that law in itself produces the notion of dignity-in competition with, for instance, moral philosophy: Jeremy Waldron, Dignity, Rank, and Rights (Oxford: Oxford University Press, 2015)

30. Hannah Arendt, The Origins of Totalitarianism, 2nd ed. (New York: Harcourt Brace, 1973).

3I. Importantly, this is also precisely what makes the fundamental difference between an international bill of rights and an international declaration.

32. Madsen and Verschraegen, Making Human Rights Intelligible, 8.

33. Emilie M. Hafner-Burton and James Ron, "Seeing Double: Human Rights Impact through Qualitative and Quantitative Eyes," World Politics 61, no. 2 (April 2009): 362.

34. Jeremy Waldron, "How Law Protects Dignity," Cambridge Law Journal 71, no. I (March 20I2): 200-222.

35. Talcott Parsons, The System of Modern Societies (Englewood Cliffs, N.J.: Prentice Hall, I97I), 27.

36. Joas, The Sacredness of the Person, I8I.

37. Ibid., I82.

38. Susan Waltz, "Reclaiming and Rebuilding the History of the Universal Declaration of Human Rights," Third World Quarterly 23, no. 3 (2002): 437-48.

39. Michael Geyer, "The Disappearance of Human Rights Post-I8oo: With an Eye on the Situation Post-200o," unpublished conference paper; Jan Eckel, "Human Rights and Decolonization: New Perspectives and Open Questions,” Humanity I, no. I (Fall 20I0): III-35; Moyn, The Last Utopia.

40. Roland Burke, Decolonization and the Evolution of International Human Rights (Philadelphia: University of Pennsylvania Press, 20II); Fabian Klose, Human Rights in the Shadow of Colonial Violence: The Wars of Independence in Kenya and Algeria (Philadelphia: University of Pennsylvania Press, 20I3); Mikael Rask Madsen, "Human Rights and the Hegemony of Ideology: European Lawyers and the Cold War Battle over International Human Rights," in Lawyers and the Construction of Transnational Justice, ed. Yves Dezalay and Bryant Garth (Milton Park, UK: Routledge, 2012), 258-76; A. W. Brian Simpson, Human Rights and the End of Empire: Britain and the Genesis of the European Convention (Oxford: Oxford University Press, 2004).

4I. For example, Stefan-Ludwig Hoffmann, "Introduction: Genealogies of Human Rights," in Human Rights in the Twentieth Century, ed. Hoffmann, I-26.

42. We will not discuss this further here, but we generally find the distinction between the national and international levels of human rights to be of more legal than sociological explanatory value.

43. The importance of this argument is, however, as a means to challenging and providing a corrective to the rather triumphalist historical literature on human rights that emerged in the late I990s and early 2000 s.

44. Éric Agrikoliansky, La ligue française des droits de l'Homme et du citoyen depuis 1945: Sociologie d'un engagement civique (Paris: L'Harmattan, 2002).

45. Christophe Charle, Les intellectuels en Europe au XIXe siècle: Essai d'histoire comparée (Paris: Seuil, 1996).

46. Max Weber, The Protestant Ethic and the Spirit of Capitalism, trans. Talcott Parsons (New York: Routledge, 200I).

47. Joas, The Sacredness of the Person, I86; Jay Winter and Antoine Prost, René Cassin and 
Human Rights: From the Great War to the Universal Declaration (Cambridge: Cambridge University Press, 2013); Glenda Sluga "René Cassin: Les droits de l'homme and the Universality of Human Rights, 1945-1966," in Human Rights in the Twentieth Century, 107-23.

48. Winter and Prost, Rene Cassin and Human Rights, I6I.

49. Simpson, Human Rights and the End of Empire, 390.

50. Hersch Lauterpacht, An International Bill of Rights of Man (New York: Columbia

University Press, 1945), 9.

5I. Joas, The Sacredness of the Person, I87.

52. The European Convention of Human Rights being a good example, see Mikael Rask Madsen, "The Protracted Institutionalisation of the Strasbourg Court: From Legal Diplomacy to Integrationist Jurisprudence," in The European Court of Human Rights Between Law and Politics, ed. Mikael Rask Madsen and Jonas Christoffersen (Oxford: Oxford University Press, 20II), 43-6o. 53. See also Moyn, The Last Utopia.

54. Hoffmann, "Introduction: Genealogies of Human Rights," I. 